\title{
Article \\ Physico-Mechanical Properties of Particleboards Produced from Macadamia Nutshell and Gum Arabic
}

\author{
Derrick Mirindi ${ }^{1, * \mathbb{D}}$, Richard O. Onchiri ${ }^{2}$ and Joseph Thuo ${ }^{3}$ \\ 1 Department of Civil Engineering, Pan-Africa University of Agriculture and Technology, Nairobi 00200, Kenya \\ 2 Department of Building and Civil Engineering, Technical University of Mombassa, Mombassa 80100, Kenya; \\ rocharo@tum.ac.ke \\ 3 Faculty of Engineering, School of Civil Engineering, Dedan Kimathi University of Technology, \\ Nyeri 10143, Kenya; thuojn@gmail.com \\ * Correspondence: derrick.mirindi1@students.jkuat.ac.ke
}

Citation: Mirindi, D.; Onchiri, R.O.;

Thuo, J. Physico-Mechanical

Properties of Particleboards Produced from Macadamia Nutshell and Gum Arabic. Appl. Sci. 2021, 11, 11138. https://doi.org/10.3390/ app112311138

Academic Editors: Aurel Lunguleasa and Camelia Cosereanu

Received: 28 September 2021 Accepted: 19 November 2021 Published: 24 November 2021

Publisher's Note: MDPI stays neutral with regard to jurisdictional claims in published maps and institutional affiliations.

Copyright: (c) 2021 by the authors. Licensee MDPI, Basel, Switzerland. This article is an open access article distributed under the terms and conditions of the Creative Commons Attribution (CC BY) license (https:// creativecommons.org/licenses/by/ $4.0 /)$.
Abstract: Due to the rising prices and high demand for panels and the fact that formaldehyde-a known carcinogen - is used to manufacture conventional particleboard, this study investigated the suitability of particleboard formed from ground macadamia nutshells mixed with $50 \%, 40 \%$, $30 \%$, and $20 \%$ of gum Arabic and determined its physical and mechanical properties. The specific gravity, the bulk density, the $\mathrm{x}$-ray fluorescence, and the scanning electron microscopy analysis of the two materials were analyzed. After production, the particleboards were cured for 56 days in an acclimatized room; then, the physical and mechanical properties were evaluated. Particleboards mixed with 50\% gum Arabic and 50\% macadamia nutshell showed good results in terms of the lowest average values of water absorption $(9.42 \%)$ and thickness swelling $(6.22 \%)$ after $24 \mathrm{~h}$ of immersion in distilled water as well as the highest density $\left(1219.20 \mathrm{~kg} / \mathrm{m}^{3}\right)$, modulus of rupture (12.21 MPa), modulus of elasticity (1.81 GPa), internal bond strength $(1.25 \mathrm{MPa})$, and compressive strength (22.54 MPa). According to ANSI/A208.1-1999, the particleboards produced met the standard for general-purpose boards except for water absorption (WA) and thickness swelling (TS) characteristics, which were above the maximum of $8 \%$ and $3 \%$, respectively.

Keywords: particleboard; macadamia nutshell; gum Arabic; water absorption; thickness swelling; modulus of elasticity; modulus of rupture; compressive strength; tensile strength

\section{Introduction}

Global population growth is increasing the demand for wood for construction and increasing its price. This massive demand has resulted in an increase in deforestation, which is negatively influencing global climate change. Most particleboards produced are made from waste wood and urea-formaldehyde, both of which are in high demand for various applications, including building materials, work surfaces, laboratory whiteboards, and office work surfaces. To manufacture high-quality particleboard, a significant amount of binder is required. Typical particleboards are constructed utilizing wood-based components and synthetic resin adhesives or other manufactured binders. Melamine-ureaformaldehyde (MUF), polycarbonic anhydrides, triglycerides polymeric substance (PTP resin), isocyanides, urea-formaldehyde (UF), and phenol-formaldehyde (PF) are a few examples of such binders [1]. Most particleboard is made with urea-formaldehyde resins; however, the emission of formaldehyde causes negative effects on the human body such as upper respiratory tract infection, eye irritation [2,3], and even cancer [4-6]. Researchers produce panels based on natural materials such as chestnut [7] or sugarcane bagasse [8], for example.

Affordable housing is one of four main goals in Kenya's strategic plan manifested by the current government. The goals included in the strategy are to create 200,000 housing units and provide affordable quality of living for poorer Kenyans [9]. In addition, the 
approach is designed to improve the development of suitable and economical technologies and building materials. The country's population is rising steadily, and substandard housing and underdevelopment, particularly in metropolitan areas, are significantly harming lower-income people. There is government pressure to implement strategies to foster sustainable and environmentally friendly resources, which are used as substitutes for wood [10]. Agricultural waste material and non-wood plant fibers can be utilized in place of wood to produce particleboard. In many parts of the world, agricultural solid waste is discarded or burned, resulting in air pollution, toxic gas, smoke, dust, and residues that may be transferred to water sources, damaging the aquatic ecosystem [11].

Macadamia nutshell farming is a significant source of revenue for cultivators all over the world, particularly shareholder farmers in Kenya. Kenya is the world's third-largest producer of macadamia nuts and thus, there is a large amount of shells in the country [12]. Unfortunately, the enormous quantity of shells is underutilized as a byproduct. The shells are used for many applications-such as cat litter, coffee roasting, filler in the plastics industry, or organic waste for gardening [13] — and they are also used as a source of biomass as a carbon [14]. Macadamia nutshells are composed of isotropic lignocellulosic material and exhibit extraordinary properties comparable to those of wood. They have also been used to manufacture particleboard. They are composed of cellulose $(29.5 \%)$, hemicellulose $(30 \%)$, lignin (40\%), and ash content (0.31\%) [13] and have a modulus of elasticity within the range of 4.2 to $5.2 \mathrm{GPa}$ and tensile strength of $55 \mathrm{MPa}[15,16]$.

Gum Arabic is derived from the acacia Senegal tree (Acacia leguminosae), which grows in dry regions ranging from the west coast of Africa to Pakistan and India in Asia. It is one of the oldest and most effective natural gums and possesses unique properties that make it an excellent binder. It is composed of a complex mixture of glycoprotein and polysaccharides characterized by approximately $3 \%$ protein and $97 \%$ carbohydrates [17]. It has been used in different fields. For instance, it is applied as an emulsifier or thickener in the food industry [18] and has historically been used as a medical treatment for chronic renal (failure) in Sudan [19]. It has been also used as an adhesive to fabricate straw blocks [20] or particleboard made from rice husks [21], for example.

This research aims to resolve two main problems; the first is the problem with traditional particleboards (PWF) when they are installed in kitchen and bathroom countertops. They have very little moisture resistance; they swell and break apart and release formaldehyde, which causes cancer. Second, agricultural waste and the forestry industry produce high amounts of byproducts-such as macadamia nutshells, eucalyptus capsules, and pine cones [13] — which are underused in Kenya.

This study evaluates the physical and mechanical properties of manufacturing particleboard made with macadamia nutshells and gum Arabic.

\section{Materials and Methods}

\subsection{Materials}

\subsubsection{Macadamia Nutshell}

Figure 1a shows macadamia nutshell waste from the SASINI Industry in Kiambu county in the central highlands near Nairobi (Kenya).

Macadamia nutshell was crushed using an R170 Diesel Engine (Model XK06-20500296, CHANGCHAI, Changzhou, China), Figure 1b, and then sieved to obtain particles sizes between $0.3 \mathrm{~mm}$ and $2.36 \mathrm{~mm}$ according to ASTM E11 [22]. Cholake et al. [23] and Dong et al. [24] reported that using a maximum particle of $2.5 \mathrm{~mm}$ of macadamia nutshell performed the physical and mechanical properties of the panel. Then, particles were subsequently air-dried for $48 \mathrm{~h}$ to obtain a moisture content of around $10 \%$, as Ishaq et al. [25] and Sotannde et al. reported in their studies [26]. 


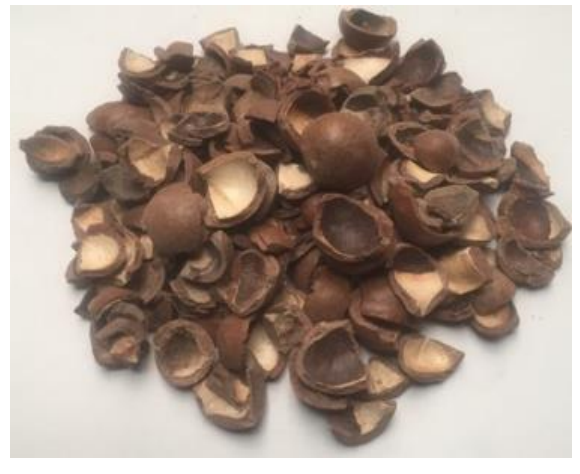

(a)

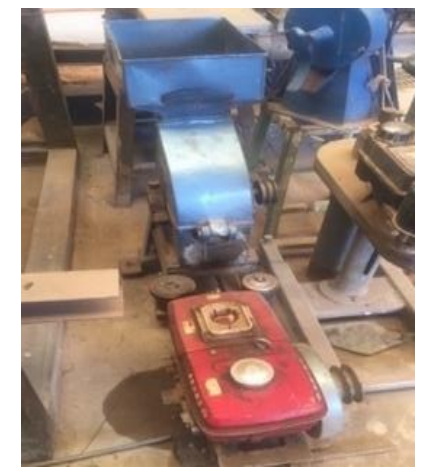

(b)

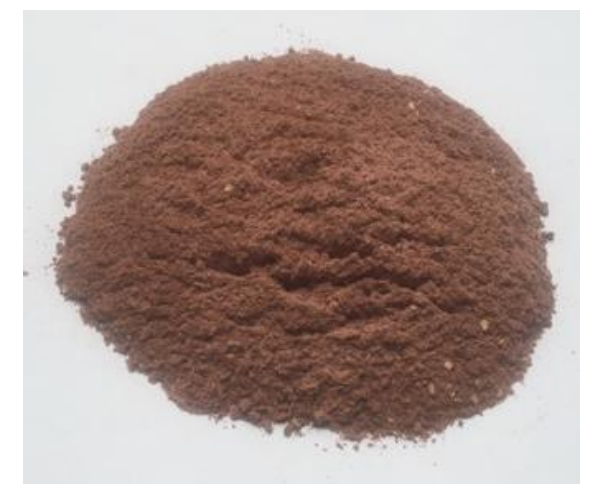

(c)

Figure 1. (a) Macadamia nutshell, (b) R170 diesel engine, (c) macadamia nutshell particle size between $0.3 \mathrm{~mm}$ and $2.36 \mathrm{~mm}$.

2.1.2. Gum Arabic

Gum Arabic, Figure 2a, was obtained in Isiolo county located in the upper east of Kenya.

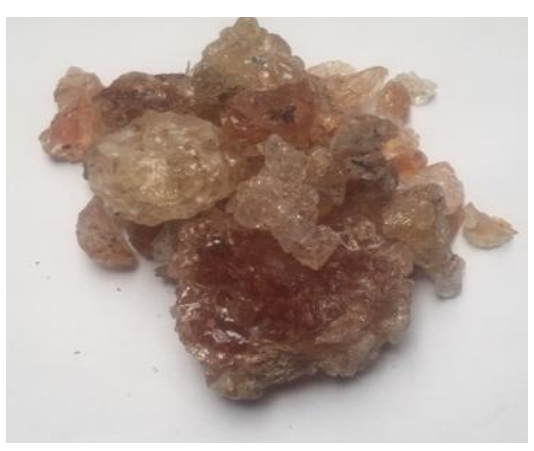

(a)

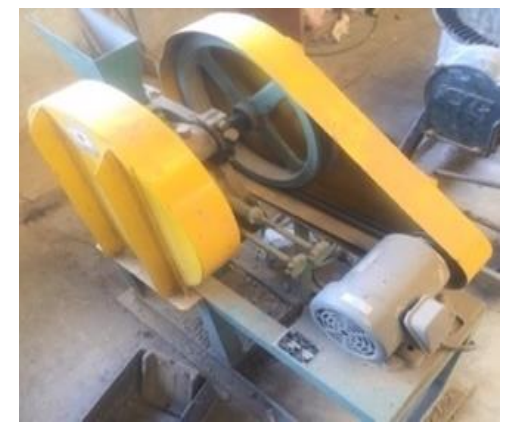

(b)

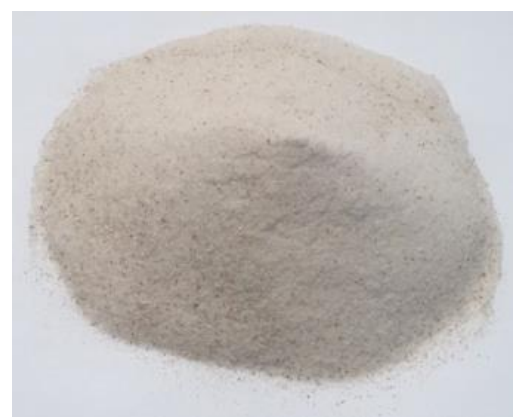

(c)

Figure 2. (a) Gum Arabic; (b) jaw crusher engine machine; (c) gum Arabic granules.

In the laboratory, gum Arabic was crushed using a jaw crusher engine machine (Model D164962, HITACHY, Tokyo, Japan), Figure 2b, then passed through a sieve size of $1.2 \mathrm{~mm}$ to remove visible impurities from tree bark particles as shown in Figure 2c. A study conducted by Njike et al. [20] showed that the proportion for gum Arabic and water that form a suitable binder is ratio 1:1 (water:gum Arabic). In this study, four ratios (1:0.5, 1:0.75, 1:1, and 1:1.25) were investigated. The result showed that the solution with ratio 1:1 formed the best binder.

The powder was subsequently mixed with potable water to obtain a homogeneous solution of $1000 \mathrm{~g}$ of gum Arabic powder per liter of water.

\subsection{Method}

\subsubsection{Specific Gravity}

The specific gravity of any material is defined as the ratio of the density of a substance to the density of a standard substance; usually, water is used for a liquid and a solid.

The specific gravity of the gum Arabic was determined the same way as that of cement by using a pycnometer according to ASTM C188-95 [27]. Kerosene was used instead of water due to the water-gum Arabic reaction, which prevented the test.

The specific gravity test of macadamia nutshell was calculated according to BS 1377 Part 2 [28] by using a pycnometer. 


\subsubsection{Bulk Density}

Bulk density is defined as the mass of the many particles of the soil material divided by the total volume they occupy. A T-scale balance, tamping rod, and straight edge were used to achieve the test. For particle size of $4.75 \mathrm{~mm}$ and under, a cylindrical metal container measuring three litres was used according to BS 812: Part 2: 1995 [29].

\subsubsection{Chemical Properties of Materials}

$\mathrm{X}$-ray fluorescence or XRF spectroscopy technique was used to determine the chemical properties of macadamia nutshell and gum Arabic using the SHIMADZU 800HS model machine (Shimadzu Corporation, Kyoto, Japan). The primary X-rays were generated by the source and directed at the sample surfaces (macadamia nutshell and gum Arabic), passing through a filter to modify the X-ray beam, and when the beam hit atoms in the samples, they reacted by generating secondary $\mathrm{X}$-rays that were collected and processed by a detector.

\subsubsection{Scanning Electron Microscope (SEM)}

The microstructures of macadamia nutshell and Arabic gum panels were analyzed using a scanning electron microscope model JCM-7000 NeoScope Benchtop SEM (JEOL Ltd., Tokyo, Japan). Specimens were mounted on SEM stubs using a carbon adhesive strip, and images were observed using NeoScope software. The shape and surface of the four different treatments were examined. The particle size and spatial distribution in each treatment were evaluated with an operating voltage of $15 \mathrm{kV}$ and a magnification of $\times 50$.

\subsubsection{Preparation of Particleboard Made from Macadamia Nutshell and Gum Arabic}

Figure 3 depicts the macadamia nutshell powder mixed thoroughly with the gum Arabic adhesive manually to obtain a uniform lump-free matrix.

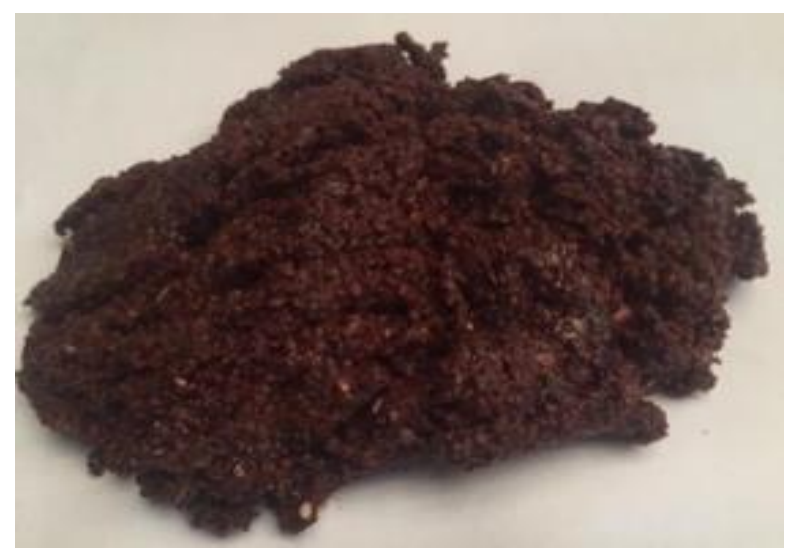

Figure 3. Mixing of gum Arabic-water-macadamia nutshell particles.

After mixing, the material was placed in a steel mat-forming box of $50 \times 15 \times 5 \mathrm{~cm}$ (Figure 4a) and manually pre-pressed using the compression tester machine engine (Model SSC-546, Marui \& Co. Ltd., Tokyo, Japan) (Figure 4c). The box was then further pressed using $155 \mathrm{~kg}$ load for $48 \mathrm{~h}$. Before board formation, the mat-forming box was covered with a polythene sheet (Figure $4 \mathrm{~b}$ ) to prevent the boards from sticking onto the box.

The particleboards produced were dried with a relative humidity of $65 \pm 2 \%$ and temperature of $20 \pm 2{ }^{\circ} \mathrm{C}$ for 56 days in the laboratory (Figure 5), then cut into different dimensions by using a circular saw bench machine (Model HS.121, Shoda Iron Work Co. Ltd., Shizuoaka, Japan) and a crosscut saw machine (Model HSC-601, Woodworking Machinery Association, Nagoya, Japan) to prepare the physical and mechanical tests. A similar process was reported by Ishaq et al. [25] and the study demonstrated good performance of the mechanical properties. 


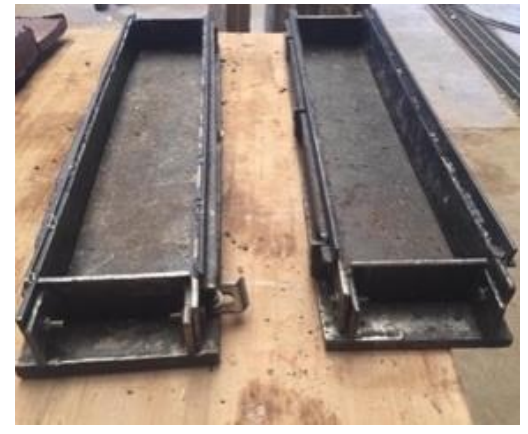

(a)

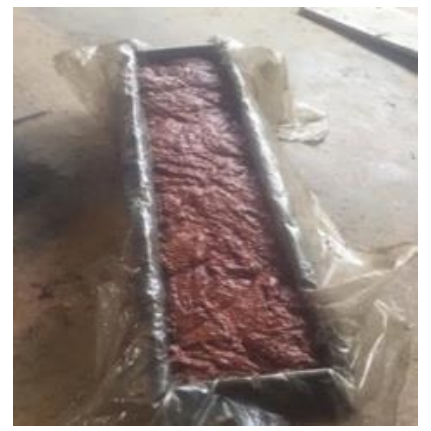

(b)

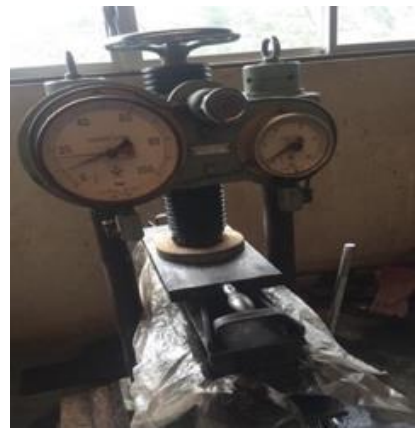

(c)

Figure 4. (a) Steel mold; (b) mixing in the mold; (c) compression of the sample under load.

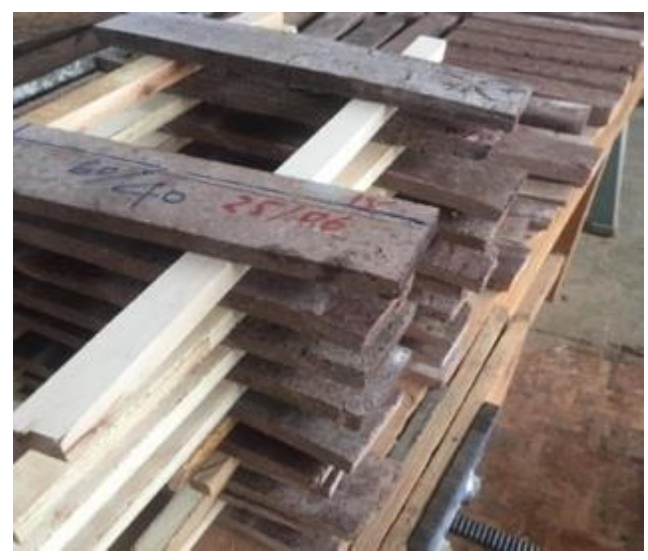

Figure 5. Particleboard storage.

The procedure used to prepare the panels and the subsequent testing regime for the macadamia nutshell/gum Arabic panels is depicted in Figure 6.

\subsubsection{Physical Properties}

Tests on physical properties were conducted by using sample size specimens of $50 \mathrm{~mm}$ length, $50 \mathrm{~mm}$ width, and $10 \mathrm{~mm}$ thick, and statistical analysis was established to obtain the means and the standard deviation.

The density of the particleboards produced was determined according to ASTM D1037-06a [30]. The length, width, and height of three replicate samples per treatment were determined using a digital veneer calliper, and the weight was recorded using a T-scale electronic balance.

The moisture content (MC) was calculated (based on the oven-dried weight) from the weights after conditioning according to ASTM D4442 [31]. Three replicate samples per treatment were weighed, then oven-dried at $103^{\circ} \mathrm{C} \pm 2{ }^{\circ} \mathrm{C}$ for $24 \mathrm{~h}$ by using the temp controller engine machine (SIGMA, Tokyo, Japan).

Water absorption (WA) and thickness swelling (TS) were obtained according to ASTM D 1037-06a [30] (the specific gravity of water was assumed to be 1.00). Three replicate samples per treatment were weighed using a T-scale electronic balance, and the thickness of each sample was recorded using a veneer calliper before and after $2 \mathrm{~h}$ and $24 \mathrm{~h}$ of submerging samples horizontally in clean water at room temperature $\left(20 \pm 2{ }^{\circ} \mathrm{C}\right)$.

\subsubsection{Mechanical Test}

The modulus of rupture (MOR) and modulus of elasticity (MOE) were determined by loading at a $4 \mathrm{~mm} / \mathrm{min}$ rate using a three-point bending test according to ASTM D1037-06 [30] section 9. The static bending test was performed using a universal testing 
machine assembly (Model: MIE TYPE 2742, MARUI \& Co., Ltd., Osaka, Japan). Five replicate samples of a dimension size of $240 \mathrm{~mm}$ length, $50 \mathrm{~mm}$ width, and $10 \mathrm{~mm}$ thick per treatment were produced and tested.

The compression strength (Rc) was measured according to ASTM D1037-06 [30] section 12 and was obtained using three replicate samples per treatment with a dimension size of $102 \mathrm{~mm}$ long, $25 \mathrm{~mm}$ wide, and $15 \mathrm{~mm}$ thick. On the other hand, the internal bond strength (IB) or tensile strength was determined according to ASTM 1036 [30] section 11 by using three replicate samples per treatment measuring $50 \times 50 \times 10 \mathrm{~mm}$. Both tests were performed using the Servo-Plus Evolution testing machine (Model: YIMC109/AB/0164, TRAVIOLO, Temù, Italy).

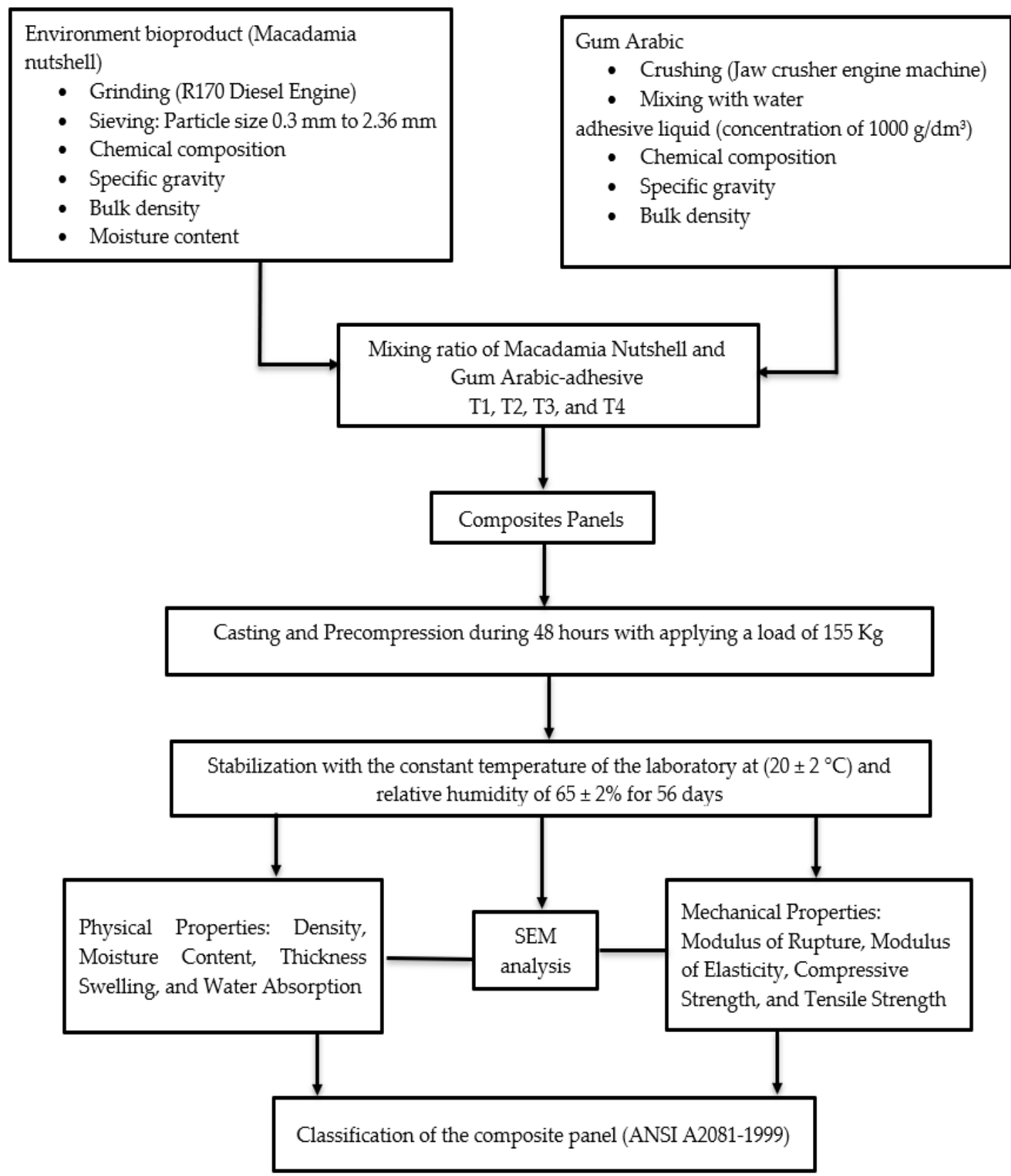

Figure 6. Flowchart used in the present study. 


\section{Results}

\subsection{Specific Gravity and Bulk Density}

The specific gravity of macadamia nutshell and gum Arabic adhesive, as shown in Table 1 below, were 1.2 and 1.55, and the compacted bulk density was $743 \mathrm{~kg} / \mathrm{m}^{3}$ and $903 \mathrm{~kg} / \mathrm{m}^{3}$, respectively. The high compacted bulk density of the macadamia nutshell and gum Arabic is a desirable property of any particleboard material. Urea-formaldehyde has a density of gravity of 1.269 [32] approximately, which is less than the gum Arabic value, and thus it can be used as an alternative material that can increase the performance of the mechanical property of panels. The highly specific gravity of gum Arabic compared to macadamia nutshell can explain the choice of the mixing ratio of the two materials established in Table 2.

Table 1. Specific gravity and bulk density.

\begin{tabular}{ccc}
\hline Sample & Specific Gravity & Bulk Density $\left(\mathbf{k g} / \mathbf{m}^{\mathbf{3}}\right)$ \\
\hline Macadamia nutshell & 1.20 & 743 \\
Gum Arabic & 1.55 & 903 \\
\hline
\end{tabular}

Table 2. Mix ratio for the production of gum Arabic and macadamia nutshell particleboard.

\begin{tabular}{ccccc}
\hline Treatment & Adhesive Type & $\mathbf{( \% )}$ & Material Type & $\mathbf{( \% )}$ \\
\hline T1 & & 20 & & 80 \\
T2 & Gum Arabic & 30 & Macadamia & 70 \\
T3 & 40 & nutshell & 60 \\
T4 & & & 50 \\
\hline
\end{tabular}

\subsection{Chemical Properties} Table 3.

The chemical properties of macadamia nutshell and gum Arabic are presented in

Table 3. Chemical properties of macadamia nutshell particles and gum Arabic.

\begin{tabular}{ccc}
\hline Elements & Macadamia Nutshell (\%) & Gum Arabic (\%) \\
\hline $\mathrm{P}_{2} \mathrm{O}_{5}$ & 21.82 & 0 \\
$\mathrm{CaO}$ & 70.84 & 56.94 \\
$\mathrm{MgO}$ & 0 & 24.4 \\
$\mathrm{~K}_{2} \mathrm{O}$ & 0 & 15.25 \\
$\mathrm{Ti}, \mathrm{Cr}, \mathrm{Mn}, \mathrm{S}$ & 5.26 & 2.80 \\
$\mathrm{Fe}, \mathrm{Cu}, \mathrm{Zn}, \mathrm{Sr}$ & 2.07 & 0.56 \\
$\mathrm{As}, \mathrm{Zr}, \mathrm{Pb}$ & 0 & 0.04 \\
\hline
\end{tabular}

The major chemical component found in both macadamia nutshell particles and gum Arabic, as shown by the laboratory test result, was calcium oxide $(71 \%$ and $57 \%)$ which is a nontoxic substance $[33,34]$. Because of the nontoxic nature of the component, macadamia nutshell and gum Arabic particleboard are environmentally beneficial, particularly when in contact with water compared to the urea-formaldehyde resin, which is toxic and releases formaldehyde, which negatively affects the human body [35].

\subsection{Scanning Electron Microscopy Analysis of the Particleboard}

The percentage of voids of any material affect the physical and mechanical properties of particleboard, and this observation was also noticed when analyzing the shape and the surfaces of the four treatments as shown by the scanning electron microscopic images in Figure 7. With a magnification of $\times 50$ and an operating voltage of $15 \mathrm{kV}$, the percentage of voids was more remarkable in the SEM T1 and SEM T2 images, corresponding to the particleboard of T1 and T2 treatment. The high number of voids in the SEM T1 and SEM 
T2 images can affect the adhesion of particles to each other, the dimensional stability, and reduce the strength of the panels. Analyzing the shape and surface in SEM T3 and SEM T4 images, there was a solidification and consolidation of the shape and the surface, and this could be due to the balanced proportion of the quantity between gum Arabic adhesive and macadamia nutshell found in treatments $\mathrm{T} 3$ and $\mathrm{T} 4$.

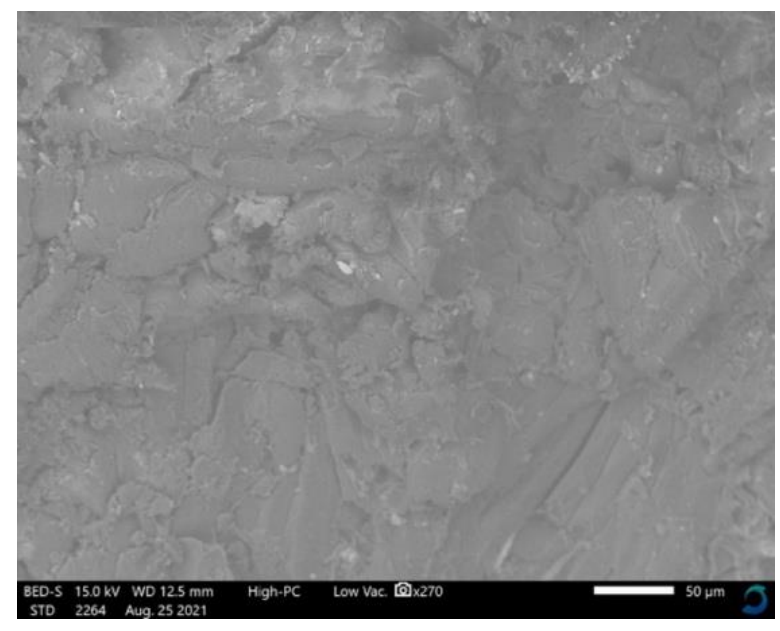

(a) SEM T1

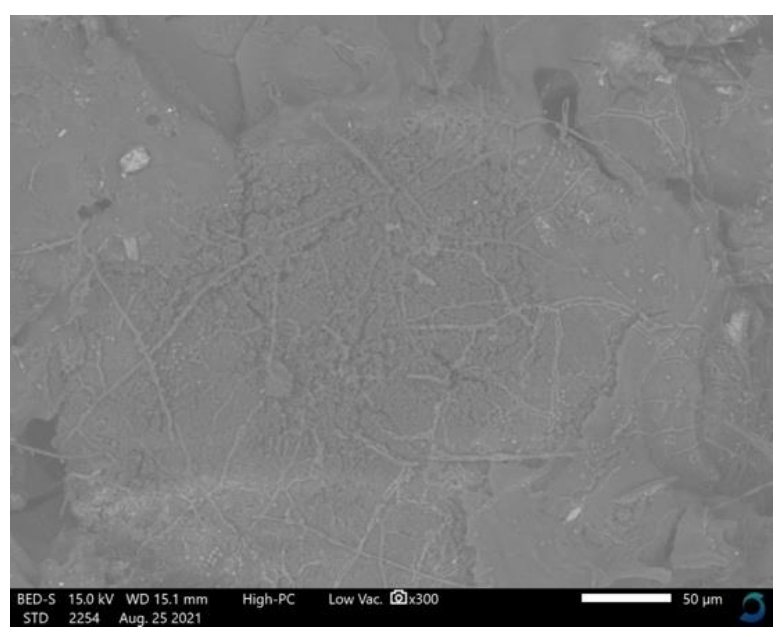

(c) SEM T3

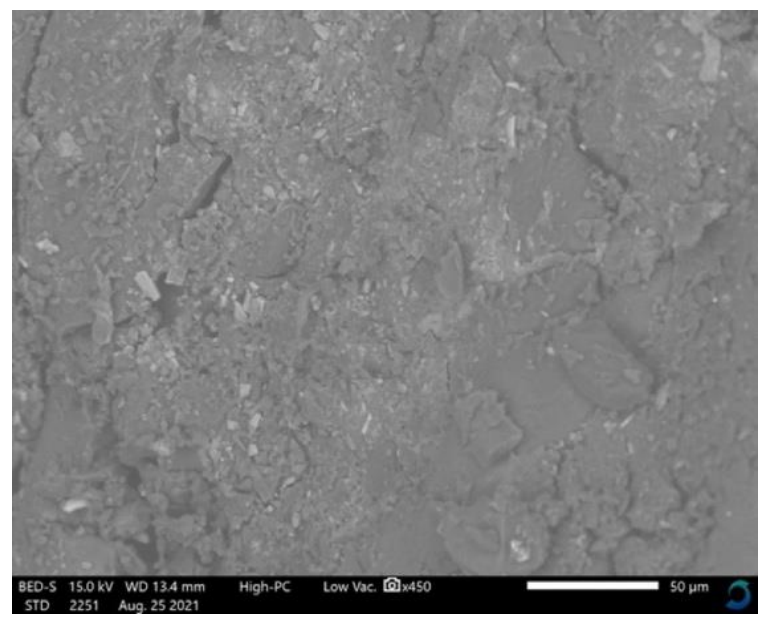

(b) SEM T2

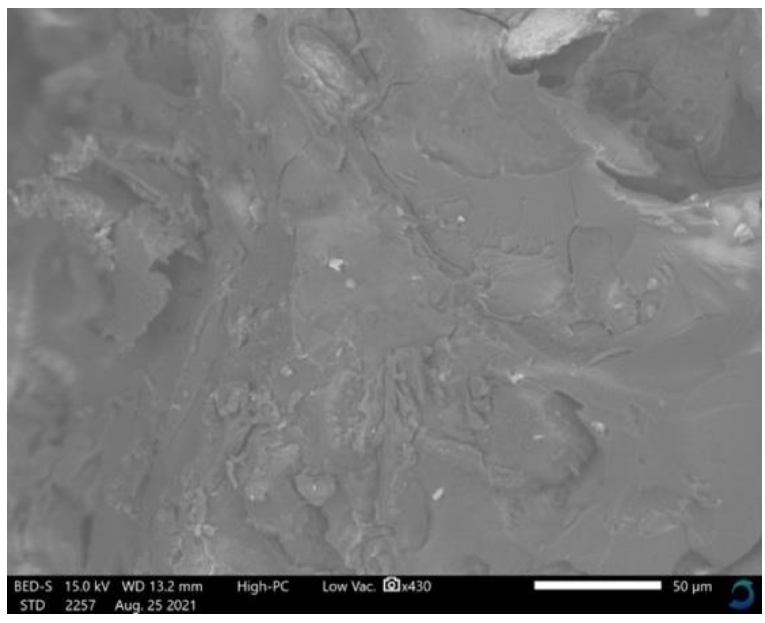

(d) SEM T4

Figure 7. SEM analysis of particleboard (a) T1, (b) T2, (c) T3, and (d) T4.

\subsection{Physical Properties}

The one-way ANOVA analysis shown in Table 4 depicted that the density presented a significant level of difference between the four treatments $\left(\mathrm{F}_{3,8}=347.97 ; p<0.05\right)$. Density values ranged between $817 \mathrm{~kg} / \mathrm{m}^{3}$ for T1 and $1219 \mathrm{~kg} / \mathrm{m}^{3}$ for T4. It showed that increasing the proportion of gum Arabic-adhesive in the mixture increased particleboard density. The highest density in T4 can be also explained by the high specific gravity of gum Arabic and macadamia nutshell and the balanced proportion of the two materials in the mixing design. On the other hand, the presence of voids in treatment T1 and T2 can explain the low-density values compared to T3 and T4.

A similar result was found by Wechsler et al. [13] by mixing $80 \%$ of macadamia nutshell and $20 \%$ castor oil, which obtained a density value of $987 \mathrm{~kg} / \mathrm{m}^{3}$, and this was due to the high density of macadamia nutshell. Moreover, Ishaq et al. [36] mixed gum Arabic with mahogany leaf particles with a proportion of gum Arabic-adhesive in the mixture 
ranging between $67 \%$ and $78 \%$, and obtained densities ranging between $1188 \mathrm{~kg} / \mathrm{m}^{3}$ and $1678 \mathrm{~kg} / \mathrm{m}^{3}$. The high-density panel could be the high specific gravity of the gum Arabic adhesive reported in that study.

Table 4. Physical properties.

\begin{tabular}{|c|c|c|c|c|c|c|}
\hline Treatment & Density $\left(\mathrm{kg} / \mathrm{m}^{3}\right)$ & MC (\%) & WA (2 h) (\%) & TS at $2 \mathrm{~h}(\%)$ & WA at $24 \mathrm{~h}(\%)$ & TS at $24 \mathrm{~h}(\%)$ \\
\hline \multirow{2}{*}{$\mathrm{T} 1$} & $818.60^{a}$ & 6.90 & 25.95 & 6.06 & 38.76 & 28.46 \\
\hline & $(15.59)^{1}$ & $(1.05)$ & $(1.64)$ & $(0.58)$ & $(3.32)$ & $(0.81)$ \\
\hline \multirow{2}{*}{$\mathrm{T} 2$} & 1067.33 & 12.18 & 12.87 & 3.33 & 24.17 & 21.67 \\
\hline & $(4.41)$ & $(0.66)$ & $(0.25)$ & $(0.58)$ & $(0.13)$ & $(0.71)$ \\
\hline \multirow{2}{*}{ T3 } & 1128.53 & 12.18 & 12.87 & 1.50 & 14.48 & 17.39 \\
\hline & (10.29) & $(0.05)$ & $(0.73)$ & $(0.50)$ & $(0.42)$ & $(1.21)$ \\
\hline \multirow[b]{2}{*}{$\mathrm{T} 4$} & 1219.20 & 13.45 & 8.12 & 0.00 & 9.42 & 6.22 \\
\hline & $(25.56)$ & $(0.12)$ & $(0.97)$ & $(0.00)$ & $(0.28)$ & $(3.30)$ \\
\hline
\end{tabular}

${ }^{\mathrm{a}}$ The mean value per treatment; ${ }^{1}$ The standard deviation per treatment represented in brackets; MC: Moisture content, WA: Water absorption, TS: Thickness swelling.

According to ANSI/A208.1-1999, the particleboard made of macadamia nutshell and gum Arabic can be classified as high-density boards $(\mathrm{H})$ since all treatments were above $800 \mathrm{~kg} / \mathrm{m}^{3}$.

The moisture content values ranged from $7 \%$ for treatment $\mathrm{T} 1$ to $13 \%$ for treatment T4. The high moisture content observed in the treatment $\mathrm{T} 4$ could be explained by the weight of the moisture coming from the gum Arabic adhesive used. The moisture content increased with the increase of the density, and one-way ANOVA analysis indicated that there was a significant difference between the four treatment particleboards at a $5 \%$ level of significance $\left(\mathrm{F}_{3,8}=58.23 ; p<0.05\right)$.

Test results showed that water absorption values ranged from $8 \%$ to $25 \%$ and $9 \%$ to $39 \%$ at 2 and $24 \mathrm{~h}$, respectively. On the other hand, the highest thickness swelling, after $2 \mathrm{~h}$ and $24 \mathrm{~h}$ of submerging samples in water, was found in treatment T1 (6\% and $28 \%$, respectively), while the lowest was found in the treatment $\mathrm{T} 4(0 \%$ and $9 \%$, respectively). One-way ANOVA analysis showed that there was a significant level of difference for the four treatments. The percentage of thickness swelling and water absorption increased with the increase in voids as depicted in the scanning electron microscopic analysis of the four treatment panels. The presence of voids in the treatment T1 and T2 particleboards affected the thickness swelling in the same way as water absorption, as these spaces increased the absorption of water of the boards and caused internal swelling [35]. Ishaq et al. [36] and Lee [35] reported that the presence of many voids in the boards allowed internal swelling. Moreover, the elevated percentage of water absorption and thickness swelling after $24 \mathrm{~h}$ could be explained by the fact that gum Arabic is dissolvable in water and thus, the reaction affected the dimensional stability of the boards.

Finally, the density value increased while the percentage of water absorption and thickness swelling decreased. The lower the density, the more the material swelled and could absorb a high amount of water in proportion with time. This is in line with the findings by Ishaq et al. [36] who reported that the swelling rate increased linearly with decreasing particleboard density.

The results of this investigation showed that the particleboard did not satisfy the recommended maximum requirement value of $8 \%$ of thickness swelling after $24 \mathrm{~h}$ provided by ANSI/A208.1-1999 for general-purse particleboards, except for treatment T4. The particleboard could not function effectively in particularly humid settings or when it came into contact with water or moisture.

\subsection{Mechanical Properties}

The one-way ANOVA analysis shown in Table 5 indicated that the modulus of rupture and modulus of elasticity presented a significant difference between the four treatments at a significance level of $5 \%\left(\mathrm{~F}_{3,16}=439.60 ; p<0.05\right.$ and $\left.\mathrm{F}_{3,16}=58.23 ; p<0.05\right)$. Treatment $\mathrm{T} 4$ 
had the highest value of modulus of rupture and modulus elasticity which was $12.21 \mathrm{MPa}$ and $1.81 \mathrm{GPa}$, respectively, while the lowest value was $4.32 \mathrm{MPa}$ and $1.05 \mathrm{GPa}$ for treatment T1. The relatively high values of modulus of rupture and modulus of elasticity recorded for treatment $\mathrm{T} 4$ could be due to the random distribution of the particles in the composites. Sotannde et al. [26] reported a similar conclusion by mixing wood residues with cement to fabricate particleboard. On the other hand, the modulus of rupture and the modulus of elasticity increased with the increase in the density of the boards, and this was due to the high specific gravity of the two materials. It was also observed that the panels did not have a good resistance in flexion, and this was due to the natural shape of the macadamia nutshell particles; adding fiber reinforcement could increase the strength. The American National Standard Institute specifies the minimum modulus of rupture and modulus of elasticity are $3.00 \mathrm{~N} / \mathrm{mm}^{2}$ and $550 \mathrm{~N} / \mathrm{mm}^{2}$, respectively, while the maximum is $23.5 \mathrm{~N} / \mathrm{mm}^{2}$ and $3100 \mathrm{~N} / \mathrm{mm}^{2}$, respectively, for general-purpose particleboards. According to the findings of this research, the boards produced using an adhesive-macadamia nutshell ratio of the four treatments met the requirements specified by the ANSI/A208.1-1999 for general-use particleboards, and only the mixing ratio of $\mathrm{T} 4$ met the minimum required for grade $\mathrm{M}-1$.

Table 5. Mechanical properties.

\begin{tabular}{ccccc}
\hline Treatment & MOR (MPa) & MOE (GPa) & IB (MPa) & Rc (MPa) \\
\hline \multirow{2}{*}{ T1 } & $4.20^{\mathrm{b}}$ & 1.05 & 1.00 & 10.88 \\
& $(0.41)^{2}$ & $(0.08)$ & $(0.02)$ & $(0.41)$ \\
T2 & 7.06 & 1.30 & 1.06 & 13.84 \\
& $(0.41)$ & $(0.03)$ & $(0.02)$ & $(0.41)$ \\
T3 & 9.91 & 1.49 & 1.16 & 19.70 \\
& $(0.40)$ & $(0.08)$ & $(0.02)$ & $(0.41)$ \\
T4 & 12.21 & 1.81 & 1.25 & 22.54 \\
& $(0.23)$ & $(0.06)$ & $(0.01)$ & $(0.41)$ \\
\hline
\end{tabular}

$\mathrm{b}^{\mathrm{b}}$ The mean value per treatment; ${ }^{2}$ The standard deviation per treatment represented in brackets; MOR: Modulus of rupture; MOE: Modulus of elasticity; IB: Internal bond; Rc: Compressive strength of particleboards.

The test results showed that the compressive strength varied in the range between $8.88 \mathrm{MPa}$ for treatment T1 and 22.54 MPa for treatment T4. The one-way ANOVA analysis reported that there was a significant level of difference between the four treatments $\left(\mathrm{F}_{3,8}=148.62 ; p<0.05\right)$. The increasing compressive strength could be due to the decreasing number of voids in treatments $\mathrm{T} 3$ and $\mathrm{T} 4$ as shown in the scanning electron microscopy images and the compaction between the macadamia nutshell particles and the gum Arabic adhesive, thereby achieving good chip-to-chip contact during the pre-compression phase. The compressive strength results were not surprising since the two materials showed desirable specific gravity and bulk density. The density of the panel increased with the increase in the compressive strength. Moreover, macadamia nutshell is known to be tough and has good resistance in compression [13].

The tensile strength value ranged between $1 \mathrm{~N} / \mathrm{mm}^{2}$ for treatment $\mathrm{T} 1$ and $1.25 \mathrm{~N} / \mathrm{mm}^{2}$ for treatment T4. The one-way ANOVA analysis showed that there was a significant level of difference for the four treatments. The tensile strength also increased with the increasing in gum Arabic adhesive in the mixing design. The high tensile strength in treatment T4 could be due to the good adhesion between the two materials, which reduced the number of voids compared to treatment T1 and T2. Moreover, the high toughness and tensile strength (55 MPa) of macadamia nut shells $[15,16,37]$ could contribute to the performance of the panels in tension.

The American National Standard Institute specifies a minimum internal bond of $0.14 \mathrm{~N} / \mathrm{mm}^{2}$ and a maximum of $1 \mathrm{~N} / \mathrm{mm}^{2}$ for general-purpose particleboards. Therefore, all the particleboards produced were above the maximum value required for general purposes. 


\section{Conclusions}

The potential for using macadamia nutshell and gum Arabic as a binder to produce particleboards was investigated. The dominant chemical property present both in macadamia nutshell and gum Arabic was calcium oxide (71\% and 57\%, respectively), which made the particleboard nontoxic compared with conventional particleboard made with urea-formaldehyde. On the other hand, the particleboards produced can be classified as high-density boards $(\mathrm{H})$ for having all the density values above $800 \mathrm{~kg} / \mathrm{m}^{3}$, which increased the mechanical properties of the particleboard. Moreover, all the tensile strength values were above the maximum required by ANSI/A208.1-1999 for particleboard due to the toughness of the macadamia nutshell and the use of gum-Arabic as a binder. Using a waterproofing substance could protect the particleboard against water absorption. Adding fiber reinforcement could be a solution to increase the strength resistance in flexion. Finally, an environmentally friendly particleboard that satisfies the ANSI/A208.1-1999 standard could be produced using macadamia nutshell and gum Arabic for a variety of applications—-such as flooring, ceiling boards, work surfaces, laboratory whiteboards, etc.

Author Contributions: Conceptualization, D.M., R.O.O. and J.T.; Formal analysis, D.M., R.O.O. and J.T.; Funding acquisition, D.M.; Methodology, D.M., R.O.O. and J.T.; Validation, R.O.O. and J.T.; Investigation, D.M., R.O.O. and J.T.; Writing-original draft preparation, D.M.; Writing-review and editing, R.O.O. and J.T.; Supervision, R.O.O. and J.T. All authors have read and agreed to the published version of the manuscript.

Funding: This research was funded by the Pan Africa University of Basic Sciences, Technology, and Innovation (PAUSTI).

Institutional Review Board Statement: Not applicable.

Informed Consent Statement: Not applicable.

Data Availability Statement: The data presented in this study are available from the corresponding author upon request.

Acknowledgments: The authors appreciate the financial support of Pan African University of Basic Sciences, Technology and Innovation (PAUSTI). We would like also to acknowledge the Department of Food Science (Fortification Laboratory, Jomo Kenyatta University of Agriculture and Technology) for providing the Scanning Electron Microscopy facility, the Ministry of Transport, Infrastructure, Housing, Urban Development and Public Works of Kenya for facilitating the chemical test. We wish to thank all staff of the Structural Laboratory of Jomo Kenyatta University of Agriculture and Technology (JKUAT), where the physical and mechanical tests were conducted.

Conflicts of Interest: The authors declare no conflict of interest.

\section{References}

1. Jafarnezhad, S.; Shalbafan, A.; Luedtke, J. Effect of surface layers compressibility and face-to-core-layer ratio on the properties of lightweight hybrid panels. Int. Wood Prod. J. 2018, 9, 164-170. [CrossRef]

2. Kim, S.; Kim, H.J. Evaluation of formaldehyde emission of pine and wattle tannin-based adhesives by gas chromatography. Holz Als Roh-Und Werkst. 2004, 62, 101-106. [CrossRef]

3. Kim, S.; Kim, H.J. Effect of addition of polyvinyl acetate to melamine-formaldehyde resin on the adhesion and formaldehyde emission in engineered flooring. Int. J. Adhes. Adhes. 2005, 25, 456-461. [CrossRef]

4. Pontel, L.B.; Rosado, I.V.; Burgos-Barragan, G.; Garaycoechea, J.I.; Yu, R.; Arends, M.J.; Chandrasekaran, G.; Broecker, V.; Wei, W.; Liu, L.; et al. Endogenous formaldehyde is a hematopoietic stem cell genotoxin and metabolic carcinogen. Mol. Cell 2015, 60, 177-188. [CrossRef]

5. Chaiklieng, S.; Tongsantia, U.; Autrup, H.N. Risk assessment of inhalation exposure to formaldehyde among workers in medical laboratories. Asia-Pac. J. Sci. Technol. 2021, 26, 4.

6. Van der Laan, L.; Cardenas, A.; Vermeulen, R.; Fadadu, R.P.; Hubbard, A.E.; Phillips, R.V.; Zhang, L.; Breeze, C.; Hu, W.; Wen, C.; et al. Epigenetic aging biomarkers and occupational exposure to benzene, trichloroethylene and formaldehyde. Environ. Int. 2022, 158, 106871. [CrossRef] [PubMed]

7. Spina, S.; Zhou, X.; Segovia, C.; Pizzi, A.; Romagnoli, M.; Giovando, S.; Pasch, H.; Delmotte, L. Phenolic resin adhesives based on chestnut (Castanea sativa) hydrolysable tannins. J. Adhes. Sci. Technol. 2013, 27, 2103-2111. [CrossRef] 
8. Garzón-Barrero, N.M.; Shirakawa, M.A.; Brazolin, S.; de Lara, I.A.R.; Savastano, H., Jr. Evaluation of mold growth on sugarcane bagasse particleboards in natural exposure and in accelerated test. Int. Biodeterior. Biodegrad. 2016, 115, 266-276. [CrossRef]

9. Towards 2030 I Kenya Vision 2030. Available online: https:/ /vision2030.go.ke/towards-2030/ (accessed on 21 June 2021).

10. Ljungberg, L.Y. Materials selection and design for development of sustainable products. Mater. Des. 2007, 28, 466-479. [CrossRef]

11. Adejumo, I.O.; Adebiyi, O.A. Agricultural Solid Wastes: Causes, Effects, and Effective Management. Solid Waste Manag. 2020, 1-460. [CrossRef]

12. Quiroz, D.; Kuepper, B.; Wachira, J.; Emmott, A. Value Chain Analysis of Macadamia Nuts in Kenya; Centre for the Promotion of Imports from Developing Countries (CBI): Amsterdam, The Netherlands, 2019.

13. Wechsler, A.; Zaharia, M.; Crosky, A.; Jones, H.; Ramírez, M.; Ballerini, A.; Nuñez, M.; Sahajwalla, V. Macadamia (Macadamia integrifolia) shell and castor (Rícinos communis) oil based sustainable particleboard: A comparison of its properties with conventional wood based particleboard. Mater. Des. 2013, 50, 117-123. [CrossRef]

14. Kumar, U.; Maroufi, S.; Rajarao, R.; Mayyas, M.; Mansuri, I.; Joshi, R.K.; Sahajwalla, V. Cleaner production of iron by using waste macadamia biomass as a carbon resource. J. Clean. Prod. 2017, 158, 218-224. [CrossRef]

15. Wang, C.H.; Mai, Y.W. Deformation and fracture of Macadamia nuts. Part 2: Microstructure and fracture mechanics analysis of nutshell. Int. J. Fract. 1994, 69, 67-85. [CrossRef]

16. Wang, C.-H.; Zhang, L.; Mai, Y.-W. Deformation and fracture of Macadamia nuts. Part 1: Deformation analysis of nut-in-shell. Int. J. Fract. 1995, 69, 51-65. [CrossRef]

17. Jaafar, N.S. Clinical effects of Arabic gum (Acacia): A mini review. Iraqi J. Pharm. Sci. 2019, 28, 9-16. [CrossRef]

18. Ademoh, N.A.; Abdullahi, A.T. Evaluation of the effective baking conditions for grade 3 Nigerian acacia species bonded foundry sand cores. Res. J. Appl. Sci. Eng. Technol. 2010, 2, 504-507.

19. Ali, B.H.; Ziada, A.; Blunden, G. Biological effects of gum arabic: A review of some recent research. Food Chem. Toxicol. 2009, 47, 1-8. [CrossRef]

20. Njike, M.; Oyawa, W.O.; Abuodha, S.O. Potential of Straw Block as an Eco-Construction Material; Springer: Cham, Switzerland, 2019; pp. 253-261. [CrossRef]

21. Suleiman, I.Y.; Aigbodion, V.S.; Shuaibu, L.; Shangalo, M. Development of eco-friendly particleboard composites using rice husk particles and gum Arabic. J. Mater. Sci. Eng. Adv. Technol 2013, 7, 75-91.

22. ASTM E11-01. Standard Specification for Wire Cloth and Sieves for Testing Purposes; ASTM: West Conshohocken, PA, USA, 1995.

23. Cholake, S.T.; Rajarao, R.; Henderson, P.; Rajagopal, R.R.; Sahajwalla, V. Composite panels obtained from automotive waste plastics and agricultural macadamia shell waste. J. Clean. Prod. 2017, 151, 163-171. [CrossRef]

24. Dong, C.; Davies, I.J. Flexural properties of macadamia nutshell particle reinforced polyester composites. Compos. Part B Eng. 2012, 43, 2751-2756. [CrossRef]

25. Ishaq, S.; Aboshio, A.; Garba, M.J.; Smith, A.S.J. Mechanical Properties of Particleboard Made from Mahogany Leaves Using Gum Arabic as Binder. Glob. Sci. J. 2020, 8, 802-812.

26. Sotannde, O.; Oluwadare, A.; Ogedoh, O.; Adeogun, P. Evaluation of cement-bonded particle board produced from afzelia africana wood residues. J. Eng. Sci. Technol. 2012, 7, 732-743.

27. ASTM C188-95. Standard Test Method for Density of Hydraulic Cement; ASTM: West Conshohocken, PA, USA, 1995.

28. British Standards Institute (BSI). BS 1377-2: 1990 Soils for Civil Engineering Purposes_Part 2: Classification; BSI: London, UK, 1990.

29. British Standards Institution. BS 812 Testing of Aggregates Part 2: Method of Determination of Density; BSI: London, UK, 1995.

30. ASTM D 1037-96a Annual Book of ASTM Standards; American Society for Testing and Materials (ASTM): Philadelphia, PA, USA, 1999; pp. 4-9.

31. ASTM Standard. D4442-07: STANDARD Test Methods for Direct Moisture Content Measurement of Wood and Wood-Base Materials; ASTM International: West Conshohocken, PA, USA, 2007.

32. Dazmiri, M.K.; Kiamahalleh, M.V.; Dorieh, A.; Pizzi, A. Effect of the initial F/U molar ratio in urea-formaldehyde resins synthesis and its influence on the performance of medium density fiberboard bonded with them. Int. J. Adhes. Adhes. 2019, $95,102440$. [CrossRef]

33. Risthaus, K.; Bürger, I.; Linder, M.; Schmidt, M. Numerical analysis of the hydration of calcium oxide in a fixed bed reactor based on lab-scale experiments. Appl. Energy 2020, 261, 114351. [CrossRef]

34. Arul, E.; Raja, K.; Krishnan, S.; Sivaji, K.; Das, S.J. Bio-Directed synthesis of calcium oxide (CaO) nanoparticles extracted from limestone using honey. J. Nanosci. Nanotechnol. 2018, 18, 5790-5793. [CrossRef] [PubMed]

35. Gao, S.; Liu, Y.; Wang, C.; Chu, F.; Xu, F.; Zhang, D. Synthesis of Lignin-Based Polyacid Catalyst and Its Utilization to Improve Water Resistance of Urea-formaldehyde Resins. Polymers 2020, 12, 175. [CrossRef] [PubMed]

36. Ishaq, S.; Aboshio, A.; Garba, M.J.; Smith, A.S.J. Particleboard produced from mahogany leaves and gum arabic as binder. Bayoro J. Eng. Technol. 2020, 15, 51-63.

37. Jennings, J.S.; Macmillan, N.H. A tough nut to crack. J. Mater. Sci. 1986, 21, 1517-1524. [CrossRef] 